International Journal of Advanced Technology in Mechanical, Mechatronics and Materials
(IJATEC)
Vol. 02, No. 2 (2021) 76-86
Institute for Research on Innovation and Industrial System (IRIS)

\title{
Torque Analysis of 2 KW BLDC (Brushless Direct Current) Motor with Speed Variations in Electric Cars E-Falco
}

\author{
Bambang Darmono ${ }^{a^{*},}$ Hadi Pranoto ${ }^{a}$ Zainal Arifin ${ }^{\mathrm{b}}$ \\ aFaculty of Engineering Technology, Universitas Mercu Buana, Jakarta, Indonesia \\ ${ }^{b}$ Departmenet of Mechanical Engineering, Universitas Mercu Buana, Jakarta, Indonesia
}

\begin{abstract}
The motor releases torque and power to drive an electric car by carrying the load from a start position until it travels at the desired speed. The KMLI E-Falco electric car uses a BLDC type electric motor with a power capacity of $2 \mathrm{~kW}$. To find out the amount of torque of a $2 \mathrm{~kW}$ BLDC motor when driving with variations in speed, it can be done by manual calculations using the torque equation and doing a dynotest. The dynotest results show that the motor torque at the speed: $1 \mathrm{~km} / \mathrm{h}$ is $1 \mathrm{Nm}, 10 \mathrm{~km} / \mathrm{h}$ is $131 \mathrm{Nm}, 13 \mathrm{~km} / \mathrm{h}$ is $228 \mathrm{Nm}, 20 \mathrm{~km} / \mathrm{h}$ is $225 \mathrm{Nm}, 30 \mathrm{~km} / \mathrm{h}$ is $219 \mathrm{Nm}, 40 \mathrm{~km} / \mathrm{h}$ is $188 \mathrm{Nm}, 50 \mathrm{~km} /$ hour is $145 \mathrm{Nm}, 60 \mathrm{~km} / \mathrm{h}$ is $113 \mathrm{Nm}$, and $70 \mathrm{~km} / \mathrm{h}$ is $85 \mathrm{Nm}$. From the results of the dynotest, it shows that the peak torque occurs at a speed of $13 \mathrm{~km} / \mathrm{h}$ at $228 \mathrm{Nm}$. Racing software installed in the controller can increase the motor torque by 3 to 4 times at a speed variation of $13-70 \mathrm{~km} / \mathrm{h}$ based on the results of the dynotest above.
\end{abstract}

Keywords: motor; BLDC; torque; speed; acceleration

DOI: $10.37869 /$ ijatec.v2i2.47

Received 29 July 2021; Accepted 1 September 2021; Available online 18 November 2021

(C) The Authors. Published by IRIS. This is an open access article under the CC BY-NC-SA license (c) (i) (2)(2)

\section{Introduction}

To reduce dependence on the use of fuel oil so that it is useful to reduce pollution and greenhouse gas emissions, one thing that can be done is to apply electric car technology [1].

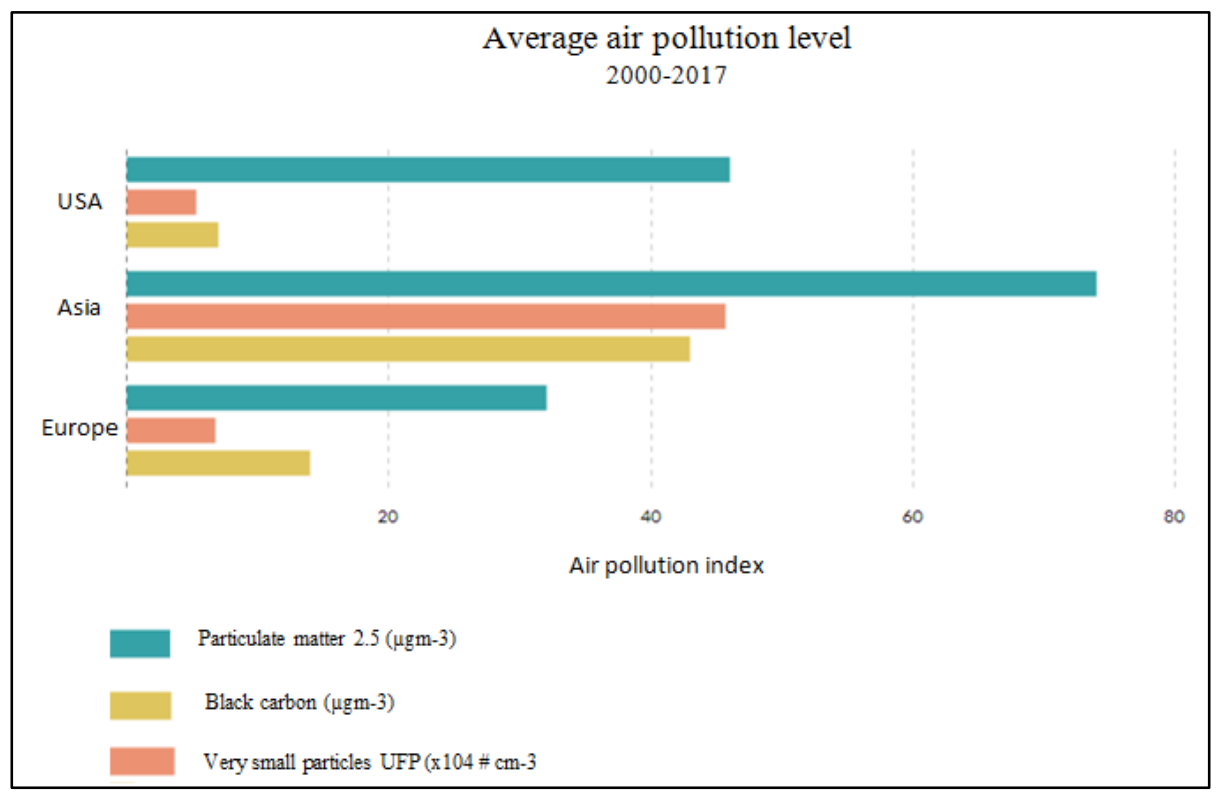

Figure 1. Average air pollution level 2000-2017 
A pure electric vehicle or Battery Electric Vehicle (BEV) uses a motor as the only source of propulsion by taking into account challenges such as dynamic road conditions, control systems and torque accuracy [2].

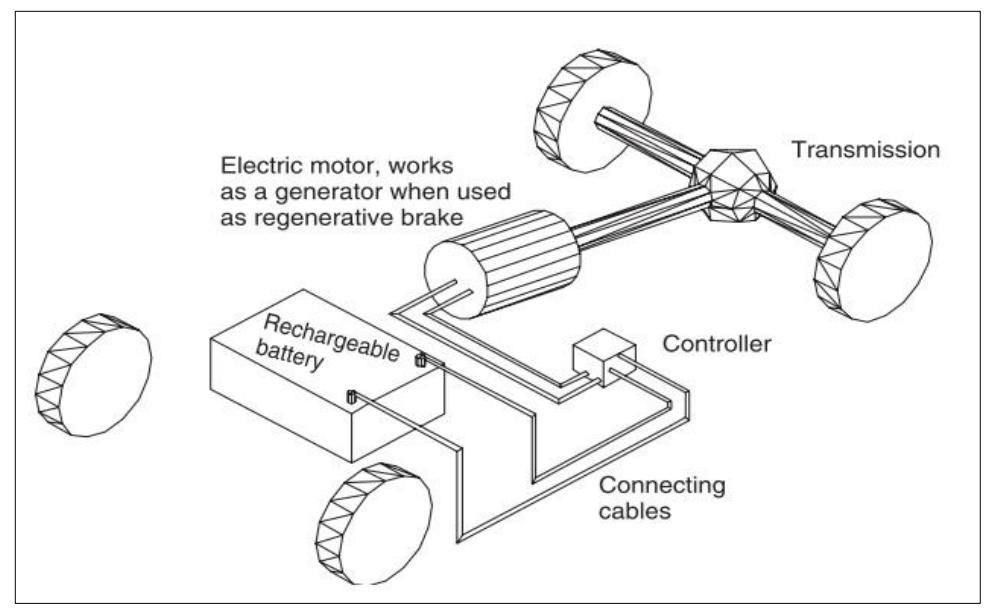

Figure 2. Battery Electric Vehicle

The driving motor used in the KMLI electric car (Indonesian Electric Car Contest) is a BLDC motor with a power of $2 \mathrm{~kW}$ because this type of motor meets the criteria and specifications required by this car. BLDC motor is a type of DC motor that does not use a brush so it does not require brush replacement maintenance and this motor has many advantages such as high efficiency, high power, high torque, high speed operation, simple drive method and low cost [3].

The motor driving the KMLI E-Falco car must be able to produce torque to move the car from the start position to speed up with a responsive acceleration speed. The motor speed-torque characteristic of electric vehicles shows that when the motor speed is still in low speed, the motor will produce high torque and when the motor speed is higher, the torque produced by the motor will decrease [4].

An electric car is a vehicle that uses an electric motor as a propulsion engine that gets energy from a battery and this car is classified into several types, namely Pure Electric Vehicle (PEV), Hybrid Electric Vehicle (HEV) and Fuel Cell Electric Vehicle (FCEV). The electric car is based on its energy source [5].

The KMLI E-Falco electric car is BEV electric car because the motor is the only driving force for the car that gets its electric power supply from the battery. The concept of a battery electric vehicle is basically simple consisting of a battery, a motor and a controller where the controller functions to control the electric power of the battery to the motor to drive the car wheels by getting an input signal from pressing the accelerator pedal [6].

The working principle of the Battery Electric Vehicle (BEV) on the KMLI electric car is the electric power from the battery is transferred to the controller then the controller determines the amount of electric power sent to the driving motor based on the accelerator pedal variable pressing, the power output varies from zero to full, based on needs [7].

\section{Methodology}

The method used to determine the amount of motor torque with variations in speed is using torque calculation and using a dynotest. The torque results from those two methods then analyzed to know the conclusions.

\subsection{Technical Data Collection}

The technical data will be used as a parameter for calculating and the dynotest. The technical data collected are dimensions, weight, motor specifications and air drag parameters. 


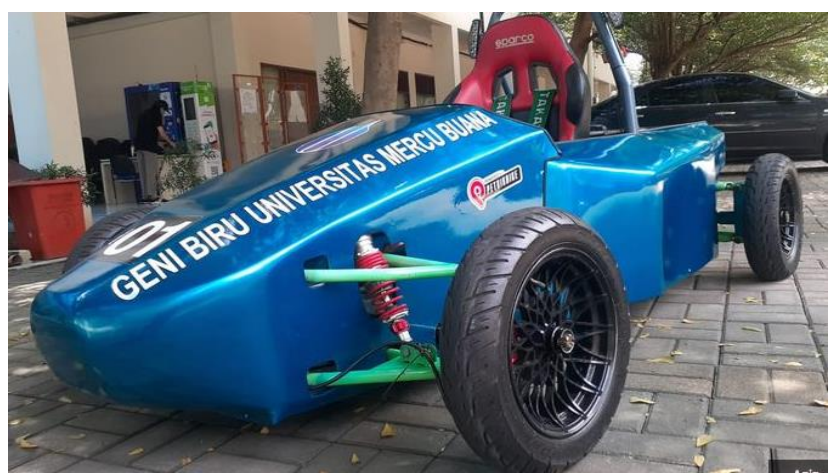

Figure 3. Electric Car KMLI E-Falco

a. Weight and Size Vehicle Data

Table 1. Vehicle Data

\begin{tabular}{lc}
\hline \multicolumn{1}{c}{ Data } & Description \\
\hline Vehicle weight & $188 \mathrm{~kg}$ \\
Length & $245 \mathrm{~cm}$ \\
Width & $134 \mathrm{~cm}$ \\
Height & $70 \mathrm{~cm}$ \\
Ground clearance & $10 \mathrm{~cm}$ \\
Wheelbase & $169 \mathrm{~cm}$ \\
Thread & $124 \mathrm{~cm}$ \\
\hline
\end{tabular}

b. Motor Specification Data

Table 2. Motor Specification

\begin{tabular}{lc}
\hline \multicolumn{1}{c}{ Data } & Description \\
\hline Rated Power & $2 \mathrm{~kW}$ \\
Rated Voltage & $48 \mathrm{~V}$ \\
Maximum Torque & $150 \mathrm{Nm}$ \\
Maximum Rpm W/O Load & $1000 \mathrm{rpm}$ \\
Peak Current & $120 \mathrm{~A}$ \\
Speed & $45-80 \mathrm{~km} / \mathrm{h}$ \\
Maximum Efficiency & $88 \%$ \\
\hline
\end{tabular}

\section{c. Gear Ratio Data}

Table 3. Gear Ratio Data

\begin{tabular}{lc}
\multicolumn{2}{c}{ Table 3. Gear Ratio Data } \\
\hline \multicolumn{1}{c}{ Data } & Description \\
\hline Driver Gear Diameter & $147 \mathrm{~mm}$ \\
Driven Gear Diameter & $180 \mathrm{~mm}$ \\
Driver Gear Teeth & 36 \\
Driven Gear Teeth & 44 \\
Gear ratio & $1.2: 1$ \\
\hline
\end{tabular}

\subsection{Motor Torque Calculation}

Calculate the motor torque in accordance with variations in speed based on weight, acceleration and travel time that can be achieved by the vehicle using the motor torque theory equation [8].

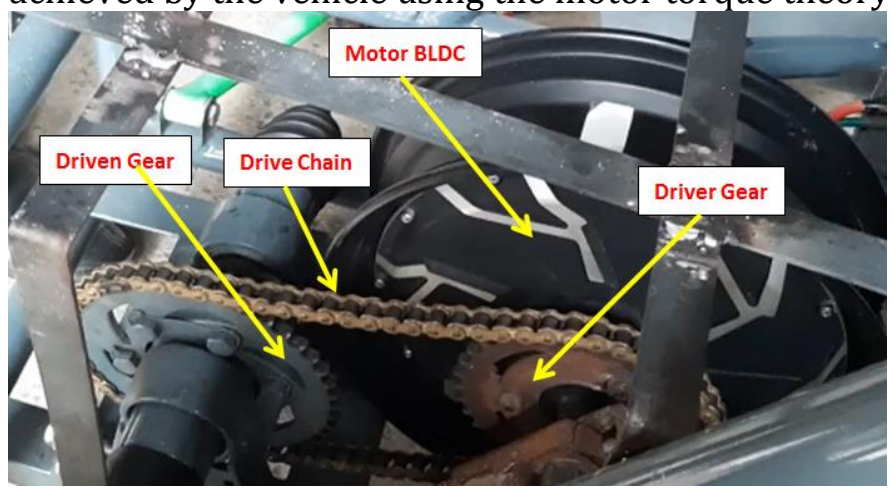

Figure 4. Drive system 
a. The Rotation Calculation of Motor and Wheel

Wheel (rpm) $=\frac{\mathrm{v} \cdot 60}{2 \cdot \pi \cdot \mathrm{wr}}$

$\operatorname{Motor}(\mathrm{rpm})=\frac{\mathrm{v} \cdot \mathrm{i} \cdot 60}{2 \cdot \pi \cdot \mathrm{wr}}$

Where $\mathrm{v}$ is vehicle speed $(\mathrm{m} / \mathrm{s}), \mathrm{i}$ is gear ratio, $\mathrm{wr}=$ wheel radius $(\mathrm{m})$.

The calculation of motor and wheel rotation (rpm) is starting from the speed $1 \mathrm{~km} / \mathrm{h}$ then continued until $70 \mathrm{~km} / \mathrm{h}$ as explanation below:

$1 \mathrm{~km} / \mathrm{h}=1000 \mathrm{~m} / 3600 \mathrm{~s}=0.28 \mathrm{~m} / \mathrm{s}$

- Wheel rotation (rpm) at speed $1 \mathrm{~km} / \mathrm{h}$ is:

$$
\text { Wheel } \mathrm{rpm}=\frac{(0.28) \cdot(60)}{(2) \cdot(3.14) \cdot(0.25)}=11 \mathrm{rpm}
$$

- Motor rotation (rpm) at speed $1 \mathrm{~km} / \mathrm{h}$ is:

$$
\text { Motor rpm }=\frac{(0.28) \cdot(1.2) \cdot(60)}{(2) \cdot(3.14) \cdot(0.25)}=13 \mathrm{rpm}
$$

\section{b. The Torque Calculation Without Motor Controller}

This calculation is to know the motor torque based on the motor rotation without any load applied on the motor. The electric power source is direct connected to the motor and without a controller to supply the electric current to the motor and the torque result is based on the motor rotation from starting rotation to high rotation. The purpose of this calculation is to know what torque difference between the BLDC motor with the controller and without the controller. This simulation as the BLDC motor characteristic below:

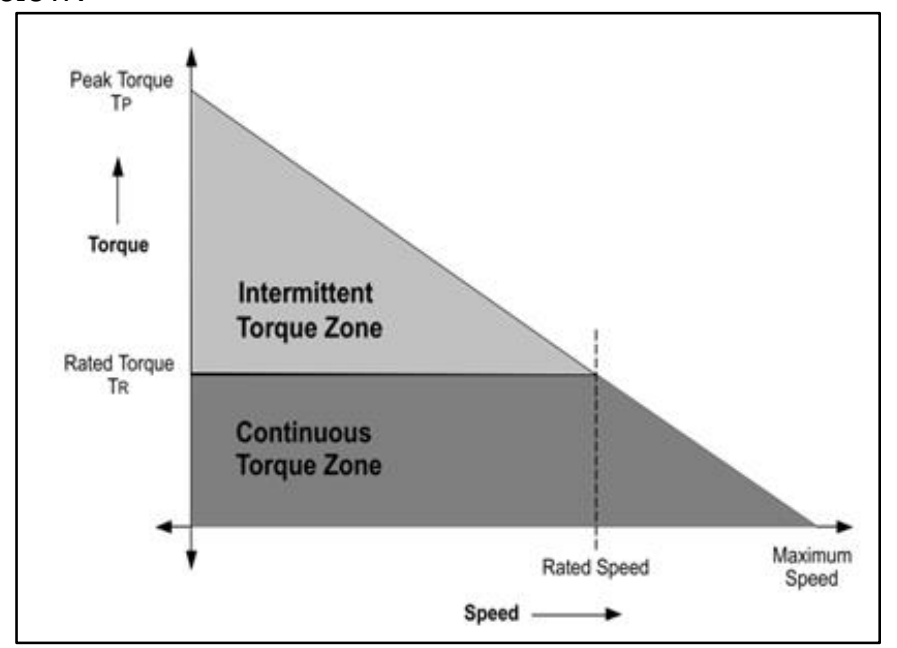

Figure 5. BLDC Motor Torque-Speed Characteristic

The torque calculation in this subject starts from the speed of $1 \mathrm{~km} / \mathrm{h}$ with motor rotation is $13 \mathrm{rpm}$.

$$
\mathrm{T}=\frac{\mathrm{P}}{\frac{2 . \pi \cdot \mathrm{n}}{60}}
$$

Where T is motor torque ( $\mathrm{Nm}$ ), $\mathrm{P}$ is power (Watt), $\mathrm{n}$ is motor rotation (rpm).

$$
\mathrm{T}=\frac{2000 \mathrm{watt}}{(2) \cdot(3.14) \cdot(13) / 60}=1470 \mathrm{Nm}
$$

\section{c. The Motor Torque Calculation Based on The Vehicle Acceleration}

Acceleration travel time used to calculate the motor torque is using the travel time of the dynotest results that have been installed the racing software in the controller. Because the results of the acceleration travel time from the dynotest are the right data as same as the travel time according to the speed under researched. 
Table 4. Travel Time According to Speed Variations

\begin{tabular}{cc}
\hline Vehicle Speed $(\mathrm{km} / \mathrm{h})$ & Travel time $(\mathrm{s})$ \\
\hline 0 to 1 & 0.04 \\
0 to 10 & 0.77 \\
0 to 13 & 1.00 \\
0 to 20 & 1.56 \\
0 to 30 & 2.41 \\
0 to 40 & 3.40 \\
0 to 50 & 4.84 \\
0 to 60 & 7.30 \\
0 to 70 & 13.63 \\
\hline
\end{tabular}

$\mathrm{a}=\frac{\Delta \mathrm{V}}{\Delta \mathrm{t}}=\frac{\left(\mathrm{V}_{1}-\mathrm{V}_{0}\right)}{\left(\mathrm{t}_{1}-\mathrm{t}_{0}\right)}$

$\mathrm{F}=\mathrm{m} \cdot \mathrm{a}$

$\mathrm{T}_{\text {wheel }}=\mathrm{T}_{\mathrm{L}}=\mathrm{F} \cdot \mathrm{r}$

$\mathrm{T}_{\text {motor }}=\frac{\mathrm{d}_{1}}{\mathrm{~d}_{2}} \cdot \frac{\mathrm{T}_{\mathrm{L}}}{\eta}$

Where $a$ is acceleration $\left(\mathrm{m} / \mathrm{s}^{2}\right), \Delta V$ is change in speed $(\mathrm{m} / \mathrm{s}), \Delta t$ is change in time $(\mathrm{s}), F$ is Force $(\mathrm{N}), r$ is wheel radius $(\mathrm{m}), d_{1}$ is diameter of driver gear $(\mathrm{m}), d_{2}$ is diameter of driven gear $(\mathrm{m}), T_{L}$ is load torque (wheel torque) (Nm).

The torque calculation based on the vehicle acceleration starts from the speed of $1 \mathrm{~km} / \mathrm{h}=0.28$ $\mathrm{m} / \mathrm{s}$.

- Vehicle acceleration (a)

$\mathrm{a}=\frac{(0.28)-(0)}{(0.04)-(0)}=7 \mathrm{~m} / \mathrm{s}^{2}$

- Force during acceleration (F)

The vehicle mass is $188 \mathrm{~kg}$ and the driver mass is $65 \mathrm{~kg}$

$\mathrm{F}=(243) .(7)=1701 \mathrm{~N}$

- Total torque on the wheel $\left(\mathrm{T}_{\mathrm{L}}\right)$

$\mathrm{T}_{\mathrm{L}}=(1701) \cdot(0.25)=425 \mathrm{Nm}$

- Motor torque $\left(\mathrm{T}_{\text {motor }}\right)$

$$
\mathrm{T}_{\text {motor }}=\frac{147}{180} \cdot \frac{425}{0,88}=395 \mathrm{Nm}
$$

\section{d. Perform the Dynotest}

Torque testing uses a dynotest machine which is a product of the Mustang Dynamometer and this is a chassis dynamometer type. The controller condition in this test is already inputted with the racing software. The purpose of racing software is to improve the torque and acceleration during driving so that this electric car will have good performance when performing the contest. The software will manage the supply of the current amount to the motor when the driver doing fast acceleration.

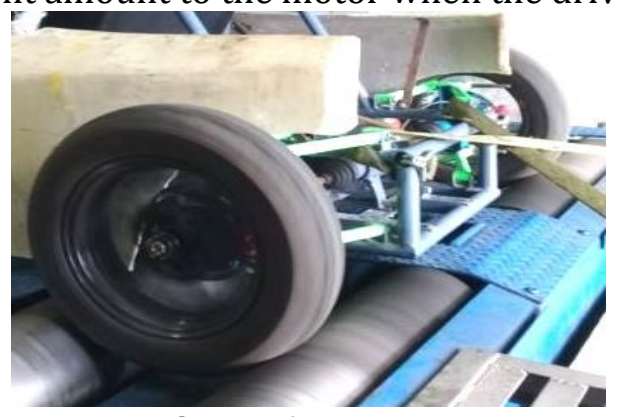

Figure 6. Dynotest 
The table below is the result of the dynotest when the electric car has accelerated from the speed of $0 \mathrm{~km} / \mathrm{h}$ to $70 \mathrm{~km} / \mathrm{h}$ with fast acceleration. The below data is the same as a printout from the computer of dynotest machine.

Table 5. Dynotest result

\begin{tabular}{ccccc}
\hline $\begin{array}{c}\text { Time } \\
(\mathrm{s})\end{array}$ & $\begin{array}{c}\text { Speed } \\
(\mathrm{km} / \mathrm{h})\end{array}$ & $\begin{array}{c}\text { Wheel Rotation } \\
(\mathrm{rpm})\end{array}$ & $\begin{array}{c}\text { Torque on the } \\
\text { Wheel }(\mathrm{Nm})\end{array}$ & $\begin{array}{c}\text { Power } \\
(\mathrm{hp})\end{array}$ \\
\hline 0,00 & 0,5 & 7 & 0 & 0 \\
0,50 & 6,6 & 89 & 25 & 4 \\
1,00 & 13,0 & 177 & 279 & 7 \\
1,50 & 19,3 & 263 & 276 & 10 \\
2,00 & 25,3 & 346 & 270 & 13 \\
2,50 & 31,0 & 424 & 267 & 16 \\
3,00 & 36,4 & 498 & 250 & 17 \\
3,50 & 41,0 & 561 & 224 & 17 \\
4,00 & 44,8 & 613 & 202 & 17 \\
4,50 & 48,0 & 658 & 187 & 17 \\
5,00 & 50,9 & 697 & 174 & 17 \\
5,50 & 53,3 & 731 & 163 & 17 \\
6,00 & 55,5 & 760 & 155 & 16 \\
6,50 & 57,4 & 786 & 147 & 16 \\
7,00 & 59,1 & 810 & 142 & 16 \\
7,50 & 60,6 & 830 & 136 & 16 \\
8,00 & 61,9 & 849 & 132 & 16 \\
8,50 & 63,1 & 865 & 127 & 15 \\
9,00 & 64,2 & 880 & 123 & 15 \\
9,50 & 65,2 & 893 & 119 & 15 \\
10,00 & 66,0 & 905 & 117 & 15 \\
10,50 & 66,8 & 915 & 114 & 15 \\
11,00 & 67,4 & 925 & 112 & 15 \\
11,50 & 68,1 & 933 & 110 & 14 \\
12,00 & 68,6 & 941 & 108 & 14 \\
12,50 & 69,1 & 947 & 106 & 14 \\
13,00 & 69,5 & 953 & 104 & 14 \\
13,50 & 69,9 & 959 & 102 & \\
14,00 & 70,3 & 964 & 101 & 14 \\
14,50 & 70,6 & 968 & & 14 \\
15,00 & 70,9 & 972 & & \\
\hline
\end{tabular}

The dynotest table data above can be used to find the travel time, speed, wheel rotation, and wheel torque by using an interpolation formula:

$\mathrm{Y}=\mathrm{Y}_{1}+\left(\frac{\mathrm{X}-\mathrm{X}_{1}}{\mathrm{X}_{2}-\mathrm{X}_{1}}\right)\left(\mathrm{Y}_{2}-\mathrm{Y}_{1}\right)$.

\section{Results and Discussions}

The torque data that has been obtained will be used for analysis so that the results of the analysis can be used to improve the acceleration speed capability.

\subsection{The Result of Torque Calculation Based on the Motor Without Controller}

The table below is showing the result of the torque calculation without motor controller and the torque calculation is based on the motor rotation from low to high rotation speed when the motor is connected to an electric power source directly.

Table 6. Torque without Motor Controller

\begin{tabular}{cccc}
\hline $\begin{array}{c}\text { Speed } \\
(\mathrm{km} / \mathrm{h})\end{array}$ & $\begin{array}{c}\text { Speed } \\
(\mathrm{m} / \mathrm{s})\end{array}$ & $\begin{array}{c}\text { Motor Rotation } \\
(\mathrm{rpm})\end{array}$ & $\begin{array}{c}\text { Torque } \\
(\mathrm{Nm})\end{array}$ \\
\hline 1 & 0,28 & 13 & 1470 \\
10 & 2,78 & 127 & 151 \\
13 & 3,61 & 166 & 115 \\
20 & 5,56 & 255 & 75 \\
30 & 8,33 & 382 & 50
\end{tabular}




\begin{tabular}{llll}
40 & 11,11 & 510 & 38 \\
50 & 13,89 & 637 & 30 \\
60 & 16,67 & 764 & 25 \\
70 & 19,44 & 892 & 21 \\
\hline
\end{tabular}

3.2The Result of Torque Calculation Based on the Acceleration

The table below is showing the result of the torque calculation based on the vehicle acceleration.

Table 7. Torque Based on the Acceleration

\begin{tabular}{cc}
\hline Speed $(\mathrm{km} / \mathrm{jam})$ & Motor Torque $(\mathrm{Nm})$ \\
\hline 1 & 395 \\
10 & 204 \\
13 & 204 \\
20 & 201 \\
30 & 195 \\
40 & 184 \\
50 & 162 \\
60 & 129 \\
70 & 80 \\
\hline
\end{tabular}

3.3The Torque Based on the Dynotest Result on the Speed of $1 \mathrm{~km} / \mathrm{h}, 10 \mathrm{~km} / \mathrm{h}, 13 \mathrm{~km} / \mathrm{h}, 20 \mathrm{~km} / \mathrm{h}, 30$ $\mathrm{km} / \mathrm{h}, 40 \mathrm{~km} / \mathrm{h}, 50 \mathrm{~km} / \mathrm{h}, 60 \mathrm{~km} / \mathrm{h}$ and $70 \mathrm{~km} / \mathrm{h}$

The table below is showing the torque of motor based on the dynotest result on the Speed of $1 \mathrm{~km} / \mathrm{h}$, $10 \mathrm{~km} / \mathrm{h}, 13 \mathrm{~km} / \mathrm{h}, 20 \mathrm{~km} / \mathrm{h}, 30 \mathrm{~km} / \mathrm{h}, 40 \mathrm{~km} / \mathrm{h}, 50 \mathrm{~km} / \mathrm{h}, 60 \mathrm{~km} / \mathrm{h}$ and $70 \mathrm{~km} / \mathrm{h}$.

Table 8. Torque Based on the Dynotest

\begin{tabular}{cccccc}
\hline $\begin{array}{c}\text { Speed } \\
(\mathrm{km} / \mathrm{h})\end{array}$ & $\begin{array}{c}\text { Travel } \\
\text { Time }(\mathrm{s})\end{array}$ & $\begin{array}{c}\text { Wheel Rotation } \\
\text { Based on } \\
\text { Dynotest }(\mathrm{rpm})\end{array}$ & $\begin{array}{c}\text { Motor Rotation } \\
\text { Based on Wheel } \\
\text { Rotation }(\mathrm{rpm})\end{array}$ & $\begin{array}{c}\text { Wheel Torque } \\
\left(\mathrm{T}_{\mathrm{L}}\right) \text { Based on } \\
\text { Dynotest }(\mathrm{Nm})\end{array}$ & $\begin{array}{c}\text { Motor Torque } \\
(\mathrm{Nm}),=\frac{\mathbf{D}_{\mathbf{1}}}{\mathbf{D}_{\mathbf{2}}} \cdot \mathbf{T}_{\mathbf{L}}\end{array}$ \\
\hline 1 & 0,04 & 14 & 17 & 2 & 1 \\
10 & 0,77 & 136 & 167 & 160 & 131 \\
13 & 1,00 & 177 & 217 & 279 & 228 \\
20 & 1,56 & 273 & 334 & 275 & 225 \\
30 & 2,41 & 410 & 502 & 268 & 219 \\
40 & 3,40 & 547 & 670 & 230 & 188 \\
50 & 4,84 & 685 & 839 & 178 & 145 \\
60 & 7,30 & 822 & 1006 & 138 & 13 \\
70 & 13,63 & 960 & 1176 & 104 & 85 \\
\hline
\end{tabular}

The table above showing that peak torque appears at the speed of $13 \mathrm{~km} / \mathrm{h}$ with the motor torque is $228 \mathrm{Nm}$.

3.4The Torque Comparation Between the Result of Torque Calculation and the Dynotest This subject will explain the torque based on the calculation and dynotest result. The table and the graph below are showing about the numbers of torque based on the calculation and dynotest result.

Table 9. Torque Comparison between the Result of Torque Calculation and the Dynotest

\begin{tabular}{cccc}
\hline $\begin{array}{c}\text { Vehicle Speed } \\
(\mathrm{km} / \mathrm{h})\end{array}$ & $\begin{array}{c}\text { Torque Calculation Based } \\
\text { on The Motor Rotation } \\
(\mathrm{Nm})\end{array}$ & $\begin{array}{c}\text { Torque Calculation Based on } \\
\text { The Vehicle Acceleration } \\
(\mathrm{Nm})\end{array}$ & $\begin{array}{c}\text { Torque Based on The } \\
\text { Dynotest (Nm) }\end{array}$ \\
\hline 1 & 1470 & 395 & 1 \\
10 & 151 & 204 & 131 \\
13 & 115 & 204 & 228 \\
20 & 75 & 201 & 225 \\
30 & 50 & 195 & 219 \\
40 & 38 & 184 & 188 \\
50 & 30 & 162 & 145 \\
60 & 25 & 129 & 113 \\
70 & 21 & 80 & 85 \\
\hline
\end{tabular}




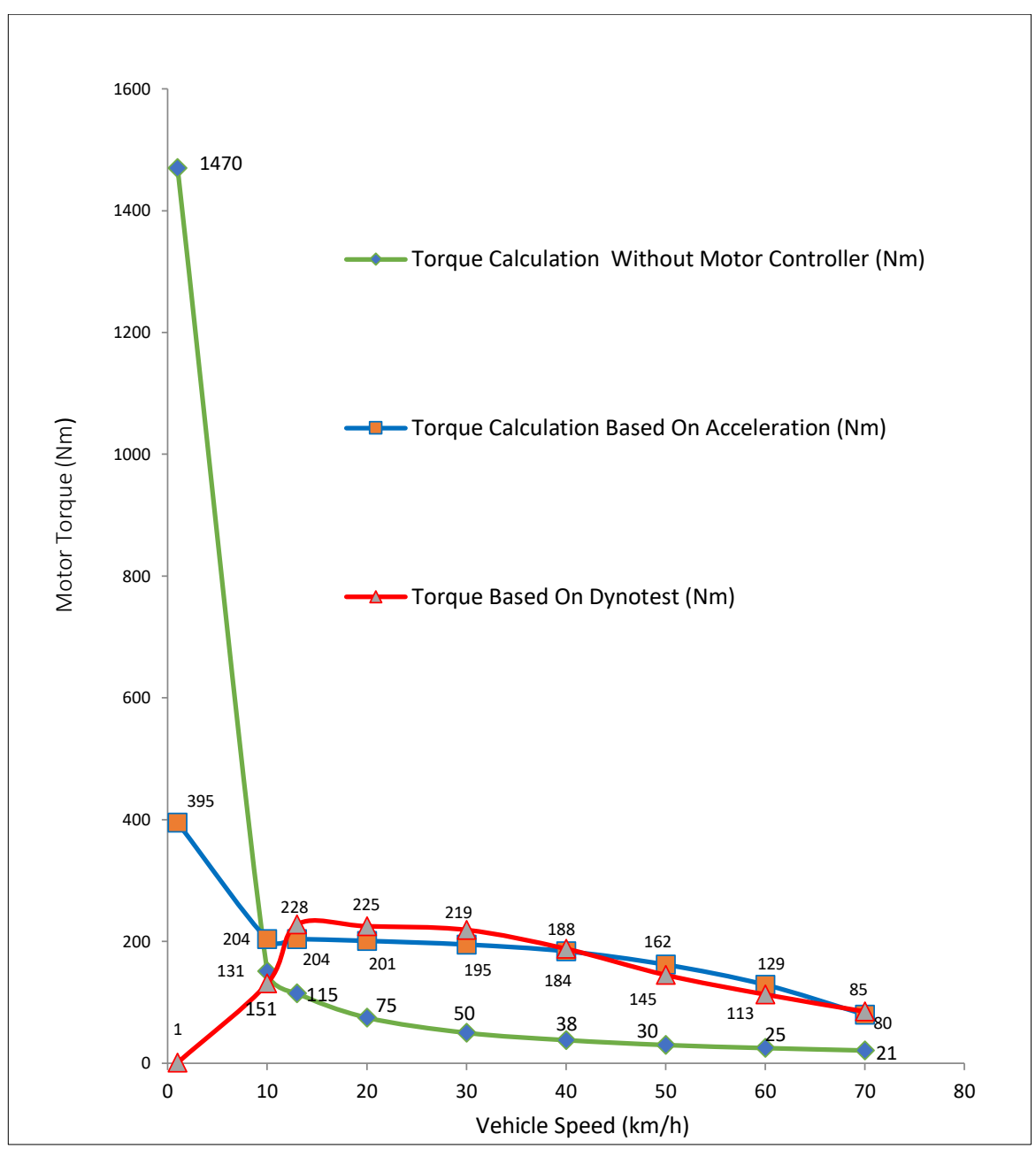

Figure 7. Graphic of Torque Comparison

\subsection{The Analysis of Torque Between Motor Specification and Dynotest Result}

The information from table 2 is mentioned that the maximum torque/ peak torque of BLDC motor used for this electric car is $150 \mathrm{Nm}$ with a peak current $120 \mathrm{~A}$. But if we see from the data of dynotest result, the motor peak torque can reach $228 \mathrm{Nm}$ at speed of $13 \mathrm{~km} / \mathrm{h}$ and at speed of $70 \mathrm{~km} / \mathrm{h}$ can reach $80 \mathrm{Nm}$. This can happen in the motor torque because the working principle of the motor is different from the Internal Combustion Engine (ICE) which the torque of ICE is dependent on the size of the crankshaft journal and piston stroke. The Electric motor torque and rotation are based on the electric induction process accordingly to the amount of electric current supplied to the motor by the controller. Because this car is for race competition so that the setting of the controller is set up with a large electric current flow to the motor accordingly with the driving condition to get the fast acceleration. The software of the motor controller can be set up by inputting the normal software program so that the motor will rotate with normal torque and the motor can use a more long life. Inputting the software racing to the motor controller will possibly make the usage of motor life will be short. Figure 9 is showing that the vehicle speed is $52 \mathrm{~km} / \mathrm{h}$ and the motor controller supplied the electric current with an amount 269 Ampere and the output torque from the motor is $141 \mathrm{Nm}$.

\subsection{Torque Analysis Between the Manual Calculation and the Dynotest}

The data that has been obtained shows that the results of torque calculation and the results of the dynotest have difference results.

\section{a. Torque Analysis From the Speed of $1 \mathrm{~km} / \mathrm{h}$ to $13 \mathrm{~km} / \mathrm{h}$}

This phase is a situation where the acceleration pedal is on the way to being fully depressed, when the pedal is pressed a little, the electric power received by the motor is still small, resulting in small power output and motor torque, when the pedal is fully pressed, the electric power received by the 
motor is large, resulting in the power and torque output of the motor increases. This is making the motor torque at a speed of $1 \mathrm{~km} / \mathrm{h}$ until before $13 \mathrm{~km} / \mathrm{h}$ is smaller than manual calculations.

\section{b. Torque Analysis Between the Torque Calculation without the Motor Controller and the Dynotest Result}

The analysis of torque at a speed of $13-70 \mathrm{~km} / \mathrm{h}$ against these two methods because the pedal is fully depressed and the peak torque in the dynotest occurs at a speed of $13 \mathrm{~km} / \mathrm{h}$. It can be seen that the motor torque without motor controller compared with the results of the dynotest shown by the table below:

Table 10. Torque Camparison between Torque Calculation without motor controller and Dynotest Result

\begin{tabular}{lccccccc}
\hline \multirow{2}{*}{ Motor Torque } & \multicolumn{7}{c}{ Vehicle Speed (km/h) } \\
\cline { 2 - 8 } & 13 & 20 & 30 & 40 & 50 & 60 & 70 \\
\hline Without Motor Controller (Nm) & 115 & 75 & 50 & 38 & 30 & 25 & 21 \\
Based on The Dynotest (Nm) & 228 & 225 & 219 & 188 & 145 & 113 & 85 \\
\hline
\end{tabular}

Table 10 above shows that the racing software installed in the controller according to the results of the dynotest test is able to increase the torque up to an average of $3-4$ times from the motor torque without the motor controller.

c. Analysis of the Phenomenon on the Graphic between Torque Calculation Based on the Acceleration and the Dynotest

It can be seen that motor torque between calculation based on the acceleration compared to the results of the dynotest in the speed $13 \mathrm{~km} / \mathrm{h}-70 \mathrm{~km} / \mathrm{h}$ as shown to the table and graphic below:

Table 11. Torque Camparison between Manual Calculations Based on Acceleration and Dynotest

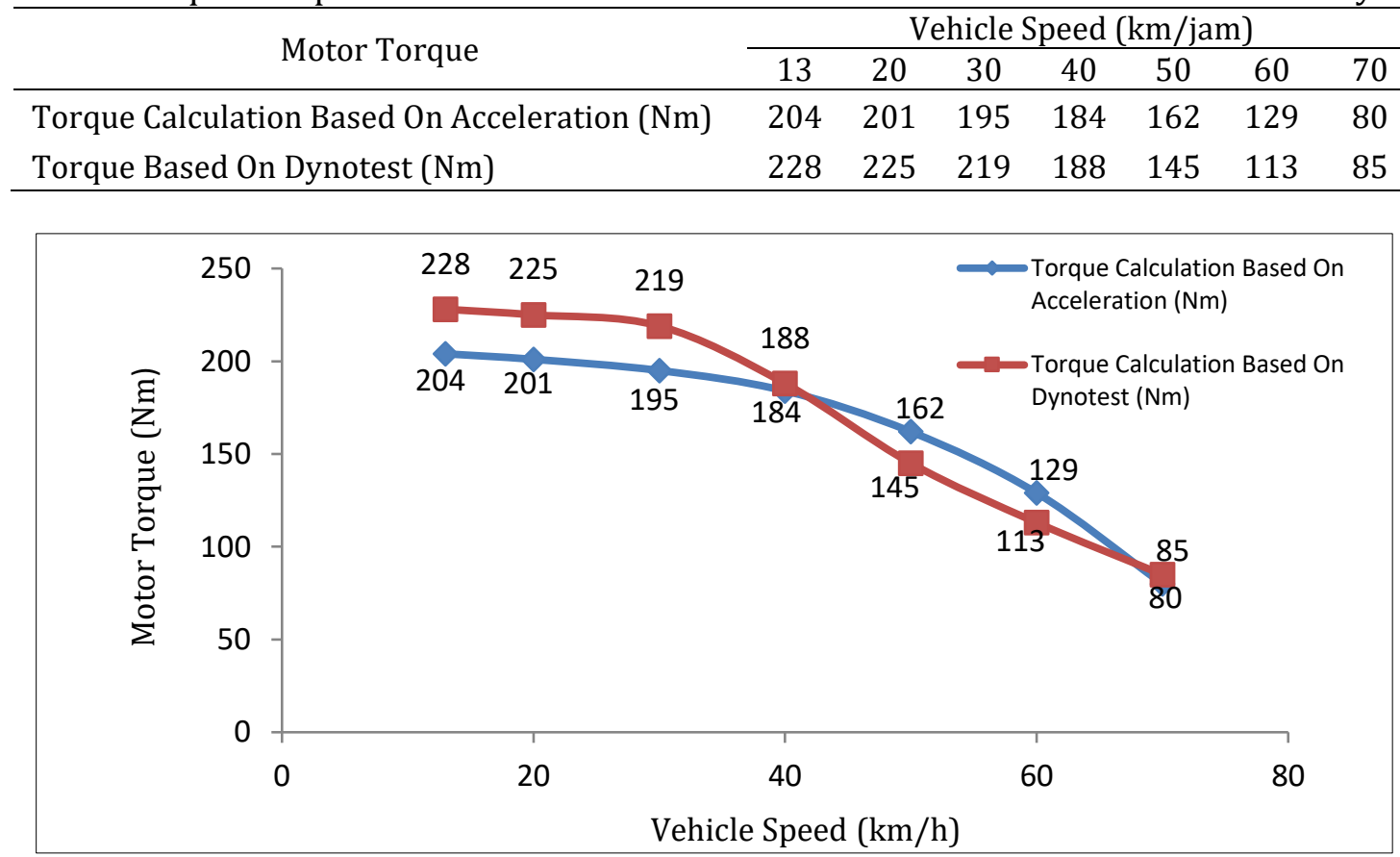

Figure 8. Graphic of Comparison between Torque Calculation Based On Acceleration and Dynotest

This phenomenon occurs because of the amount of the electric power supply from the controller to the motor at speed variations after $40 \mathrm{~km} /$ hour to before $70 \mathrm{~km} /$ hour which makes the torque figure below the graph based on calculations. It is proven by the print shot results of the electric power supply at a speed of $52 \mathrm{~km} / \mathrm{h}$ with the following calculations: 


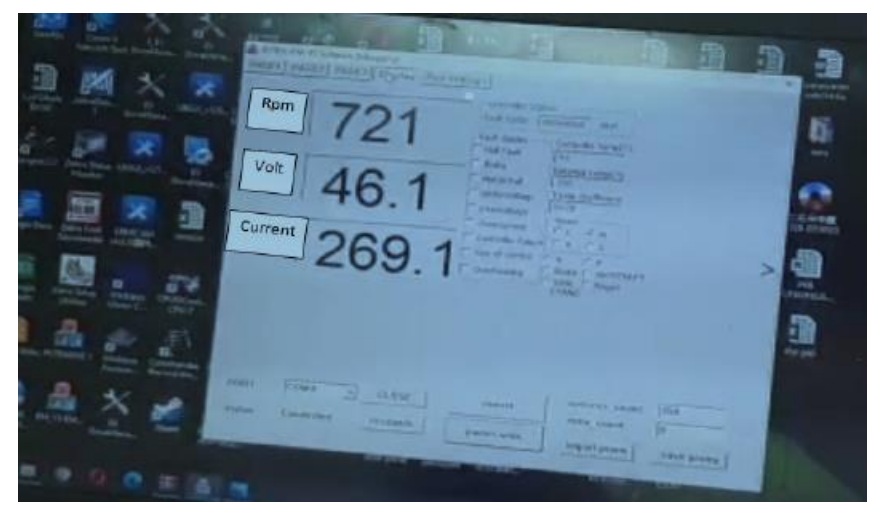

Figure 9. Current and Voltage Supply From Controller to Motor

From that above data that total current supplied to the motor is 269.1 ampere with voltage 46.1 volt and motor rotation is $721 \mathrm{rpm}$. Motor rotation $721 \mathrm{rpm}$ is equal with vehicle speed $52 \mathrm{~km} / \mathrm{h}$. From those data we can proofed the torque is below then torque calculation based on the acceleration.

Motor power, $\mathrm{P}_{\mathrm{el}}=46$ volt $\times 269$ ampere $=1241$ Watt

Torque of motor,

$\mathrm{T}_{\text {in }}=\frac{169}{1,2}=141 \mathrm{Nm}$

When compared with the torque calculation based on the acceleration at $52 \mathrm{~km} / \mathrm{h}$ is $155 \mathrm{Nm}$, it is evident that the torque number of the dynotest results is below the torque calculation on the graph with the electric power supply to the motor is 1241 Watt.

\section{Conclusions}

From the results of the research and analysis above, This research concludes as follows:

1. The results of manual calculations based on motor rotation (without racing software in the controller) show that motor torque at speeds: $1 \mathrm{~km} / \mathrm{hour}=1470 \mathrm{Nm}, 10 \mathrm{~km} / \mathrm{hour}=151 \mathrm{Nm}, 20$ $\mathrm{km} /$ hour $=75 \mathrm{Nm}, 30 \mathrm{~km} /$ hour $=50 \mathrm{Nm}, 40 \mathrm{~km} /$ hour $=38 \mathrm{Nm}, 50 \mathrm{~km} /$ hour $=30 \mathrm{Nm}, 60 \mathrm{~km} /$ hour $=25 \mathrm{Nm}$, and $70 \mathrm{~km} / \mathrm{hour}=21 \mathrm{Nm}$.

2. The results of manual calculations based on acceleration (installed racing software in the controller) show that the torque released by the motor at speed: $1 \mathrm{~km} / \mathrm{h}=395 \mathrm{Nm}, 10 \mathrm{~km} / \mathrm{h}=$ $204 \mathrm{Nm}, 20 \mathrm{~km} / \mathrm{h}=201 \mathrm{Nm}, 30 \mathrm{~km} /$ hour $=195 \mathrm{Nm}, 40 \mathrm{~km} /$ hour $=184 \mathrm{Nm}, 50 \mathrm{~km} /$ hour $=162$ $\mathrm{Nm}, 60 \mathrm{~km} /$ hour $=129 \mathrm{Nm}$, and $70 \mathrm{~km} /$ hour $=80 \mathrm{~km} /$ hour.

3. The results of the dynotest test (installed racing software in the controller) show that the motor torque at speed: $1 \mathrm{~km} / \mathrm{h}=1 \mathrm{Nm}, 10 \mathrm{~km} / \mathrm{h}=131 \mathrm{Nm}, 20 \mathrm{~km} / \mathrm{h}=225 \mathrm{Nm}, 30 \mathrm{~km} / \mathrm{h}=219 \mathrm{Nm}, 40$ $\mathrm{km} / \mathrm{h}=188 \mathrm{Nm}, 50 \mathrm{~km} / \mathrm{h}=145 \mathrm{Nm}, 60 \mathrm{~km} / \mathrm{h}=113 \mathrm{Nm}$, and $70 \mathrm{~km} / \mathrm{h}=85 \mathrm{Nm}$. Peak torque occurs at a speed of $13 \mathrm{~km} / \mathrm{h}$ is $228 \mathrm{Nm}$.

4. The racing software installed in the E-Falco electric car controller is able to multiply the motor torque up to 3-4 times compared to the motor without racing software.

\section{Acknowledgments}

The authors would like to thank to RISTEK-BRIN \& Universitas Mercu Buana for their support through the founding of this research.

\section{References}

[1] Huda, M., Aziz, M., \& Tokimatsu, K. (2019). The future of electric vehicles to grid integration in Indonesia. Energy Procedia.

[2] Cai, C. L., Wang, X. G., Bai, Y. W., Xia, Y. C., \& Liu, K. (2011). Key technologies of EV motor drive system design. Procedia Engineering.

[3] Kim, S.-H. (2017). Electric Motor. In Electric Motor Control.

[4] Ramesh, M. V., Rao, G. S., Amarnath, J., Kamakshaiah, S., \& Jawaharlal, B. (2011). Speed torque characteristics of brushless DC motor in either direction on load using ARM controller. 2011 IEEE PES International Conference on Innovative Smart Grid Technologies-India, ISGT India 2011. 
[5] Chau, K. T. (2015). Electric vehicle machines and drives: Design, analysis and application. In Electric Vehicle Machines and Drives: Design, Analysis and Application.

[6] Larminie, J., \& Lowry, J. (2003). Electric Vehicle Technology Explained. In Electric Vehicle Technology Explained.

[7] Seth, Leitman Brant, B. (2009). Bulid your Own Electric Vehicle.

[8] Braun, J. (2012). Formulae Handbook. academy.maxonmotor.ch 